\title{
Strike-slip faults offshore southern Taiwan: implications for the oblique arc-continent collision processes
}

\author{
Shi-Chie Fuh ${ }^{\mathrm{a}, \mathrm{b}, *}$, Char-Shine Liu ${ }^{\mathrm{b}}$, Neil Lundberg ${ }^{\mathrm{c}}$, Donald L. Reed ${ }^{\mathrm{d}}$ \\ "Exploration and Development Research Institute, Chinese Petroleum Corporation, P.O. Box 166, Miaoli, Taiwan \\ ${ }^{b}$ Institute of Oceanography, National Taiwan University, Taipei, Taiwan \\ ' Department of Geology, Florida State University, Tallahassee, FL 32306, USA \\ d Department of Geology, San Jose State University, San Jose, CA 95192, USA
}

Received 15 February 1996; accepted 4 July 1996

\begin{abstract}
Taiwan is the site of present-day oblique arc-continent collision between the Luzon arc of the Philippine Sea plate and the Chinese continental margin. The major structural pattern revealed from marine geophysical studies in the area offshore southern Taiwan is that of a doubly-vergent orogenic belt, bounded by significant zones of thrusting on the west and east of the submarine accretionary wedge. Due to the oblique collision process, strike-slip faults could play an important role in this convergent domain. Topographic lineaments revealed from new digital bathymetry data and seismic reflection profiles confirm the existence of three sets of strike-slip faults in the collision-subduction zone offshore southern Taiwan: the $\mathrm{N}-\mathrm{S}$-trending left-lateral strike-slip faults within the Luzon volcanic arc, the NE-SW-trending right-lateral strike-slip faults across the accretionary wedge, and the NNE-SSW-trending left-lateral strike-slip faults lie in the frontal portion of the accretionary wedge. These strike-slip faults overprint pre-existing folds and thrusts and may convert into oblique thrusts or thrusts as the forearc blocks accrete to the mountain belt. A bookshelf rotation model is used to explain the observed geometrical relationships of these strike-slip fault systems. Based on this model, the counter-clockwise rotation of the forearc blocks in the area offshore southern Taiwan could have caused extrusion of the accretionary wedge material into the forearc basin. The originally continuous forearc basin is thus deformed into several closed and separate proto-collisional basins such as the Southern Longitudinal Trough and Taitung Trough. A tectonic evolution model which emphasizes on the development of various structures at different stages of the oblique arc-continent collision for the Taiwan mountain belt is proposed.
\end{abstract}

Keywords: Strike-slip faults; Oblique collision; Bookshelf rotation

\section{Introduction}

Taiwan is the site of present-day arc-continent collision (Biq, 1973; Bowin et al., 1978; Ho, 1986; Teng, 1990). This collision is oblique because

\footnotetext{
*Corresponding author. E-mail: fuhscs@cpcedri.com.tw.
}

the N-S-trending Luzon arc is colliding with the N60 E-trending Chinese continental margin (Fig. 1). Due to this oblique convergence, the arc-continent collision is propagating southward (Suppe, 1984). The area off southern Taiwan is a transitional zone where the Luzon subduction system extending northward from the Luzon island gradually turns into an 


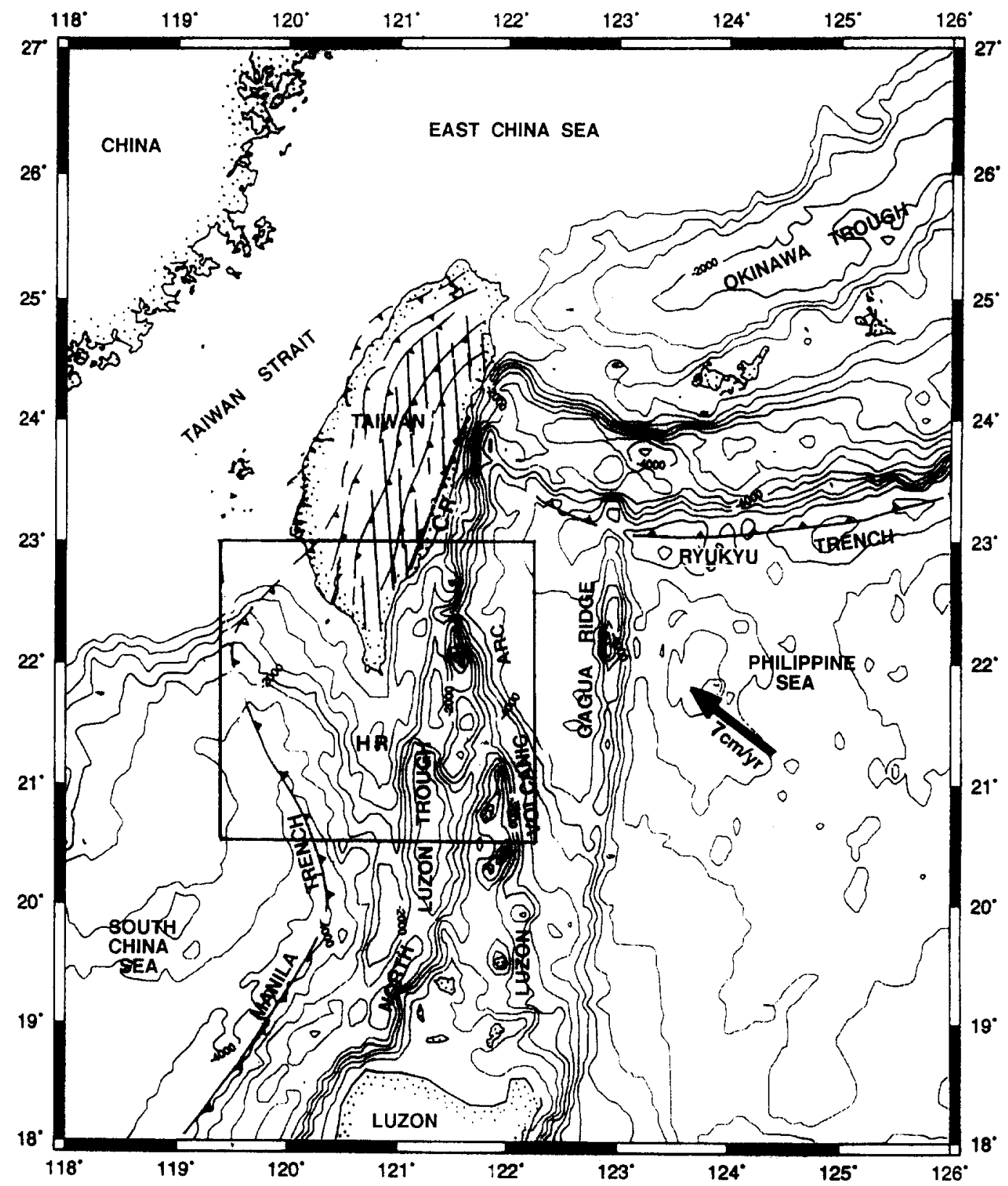

Fig. 1. Regional tectonic map of Taiwan showing the oblique are-continent collision. Bathymetry is expressed in $500 \mathrm{~m}$ contours. Large arrow indicates the plate-convergent direction between the Philippine Sea plate and the Eurasia plate. Square box indicates study area. Area shaded by vertical lines represents the Central Range. $H R=$ Hengchun Ridge. $C R=$ Coastal Range.

incipient collisional system in the area immediately southeastern of Taiwan. Major structural patterns revealed from marine geophysical studies in the area off southern Taiwan are that of an active two-sided orogen, with west-vergent imbricate thrusts devel- oped on the frontal (western) flank of the accretionary wedge and east-vergent back thrusts developed in the rear (eastern) flank of the accretionary wedge (Lundberg et al., 1991, 1992, 1997; Reed et al.. 1992). 
Since the Philippine Sea plate is moving toward the Eurasian plate in a $\mathrm{N}^{\circ} 5^{\circ} \mathrm{W}$ direction (Seno, 1977), the convergent angle defined by Beck (1983) is about $35^{\circ}$. According to Fitch (1972), decoupled transcurrent tectonics are possible at this convergence angle. Onland eastern Taiwan, the total regional shortening between the arc terrain (the Coastal Range) and the continental rocks (the Central Range) has been inferred to be about $70 \mathrm{~km}$ (Lundberg and Dorsey, 1988), but the maximum amount of shorting that occurred within the folds and thrusts in the southernmost part of the Coastal Range is estimated to be about $27 \mathrm{~km}$ (Dorsey, 1992). The remainder of the total regional contraction is most likely taken up along major faults that bound the Longitudinal Valley and some strike-slip faults which existed in the early stage of arc-continent collision. The existence of strike-slip faults in the Luzon arc-trench system offshore southern Taiwan has been suggested in many previous studies. For example, Karig (1973) proposed the existence of some left-lateral strike-slip faults of a NE-SW trend in the offshore area between Taiwan and Luzon based solely on bathymetry data. Using both bathymetry data and some focal-mechanism solutions, Lewis and Hayes (1989) proposed the existence of some left-lateral strike-slip faults of a NW-SE trend within the Luzon arc and forearc region south of Taiwan (fig. 9 of Lewis and Hayes, 1989) but no surface constraint was given. Huang et al. (1992) also inferred that some N-S-trending leftlateral strike-slip faults exist offshore southeastern Taiwan (fig. 8 of Huang et al., 1992). None of these previous studies have presented solid evidence nor mechanism for the proposed strike-slip faults. In a recent study, Fuh et al. (1994) have suggested the existence of three sets of strike-slip faults based on seismic reflection studies, and proposed a bookshelf rotation model to explain the geometric pattern of these fault systems.

Experimental modeling (Lu and Malavieille, 1994) allows one to describe the development and kinematics of mountain belts formed under oblique convergence. The kinematics of deformation comprises a combination of compression and rotation which locally result in a partitioning between thrusting and wrenching. Oblique indentation and rotation structures can be demonstrated by (1) the crescent shape of the thrust wedge, (2) pull-apart structures induced by strike-slip tectonics, and (3) bookshelftype strike-slip faulting from the block rotation around the indentation point. The southern offshore extension of the crescent shape of the thrust wedge is revealed in the study of Reed et al. (1992). A bookshelf rotation model resulting from simple shear deformation of the oblique arc-continent collision process has been proposed to explain the geometrical pattern of these strike-slip faults observed across the Luzon arc-trench system off southern Taiwan (Fuh et al., 1994). The pull-apart structures thus may also exist in this area. Analyzing the geometrical patterns of the strike-slip faults together with that of the folds and thrusts allow us to study fully the on-going arccontinent collision processes. Implications of these processes for the evolution of some proto-collisional basins such as the Southern Longitudinal Trough and the Taitung Trough can then be proposed.

In this study, a newly compiled bathymetry map which covers the area from $22^{\circ} \mathrm{N}$ to $23^{\circ} \mathrm{N}$ and from $119^{\circ} \mathrm{E}$ to $122^{\circ} 15^{\prime} \mathrm{E}$ (Fig. 2) and some new seismic reflection profiles are used to examine the evidence of the strike-slip faults in this area. We further investigate the role these strike-slip faults played in the oblique arc-continent collision processes and infer the evolution of the proto-collisional basins offshore southeastern Taiwan from the bookshelf rotation model. Finally we propose a tectonic evolutionary model of the Taiwan mountain belt based on the oblique arc-continent collision processes.

\section{Tectonic background and structural framework}

The area off southern Taiwan is a transitional zone from a typical Luzon subduction system to the south into an arc-continent collision belt to the north (Fig. 1). Onland Taiwan, the northern tip of the Luzon volcanic arc, as represented by the Coastal Range in eastern Taiwan, has already collided with the Asian continent to form the Central Range (Ho, 1986). Offshore southern Taiwan, the Lanhsu-Lutao volcanic arc is colliding with the Hengchun Peninsula, resulting in deformation of the forearc basin and uplifting of the accretionary prism material (Lundberg et al., 1992, 1997; Huang et al., 1992). Further south where no collision has occurred yet, the Manila trench, the Hengchun Ridge (accre- 


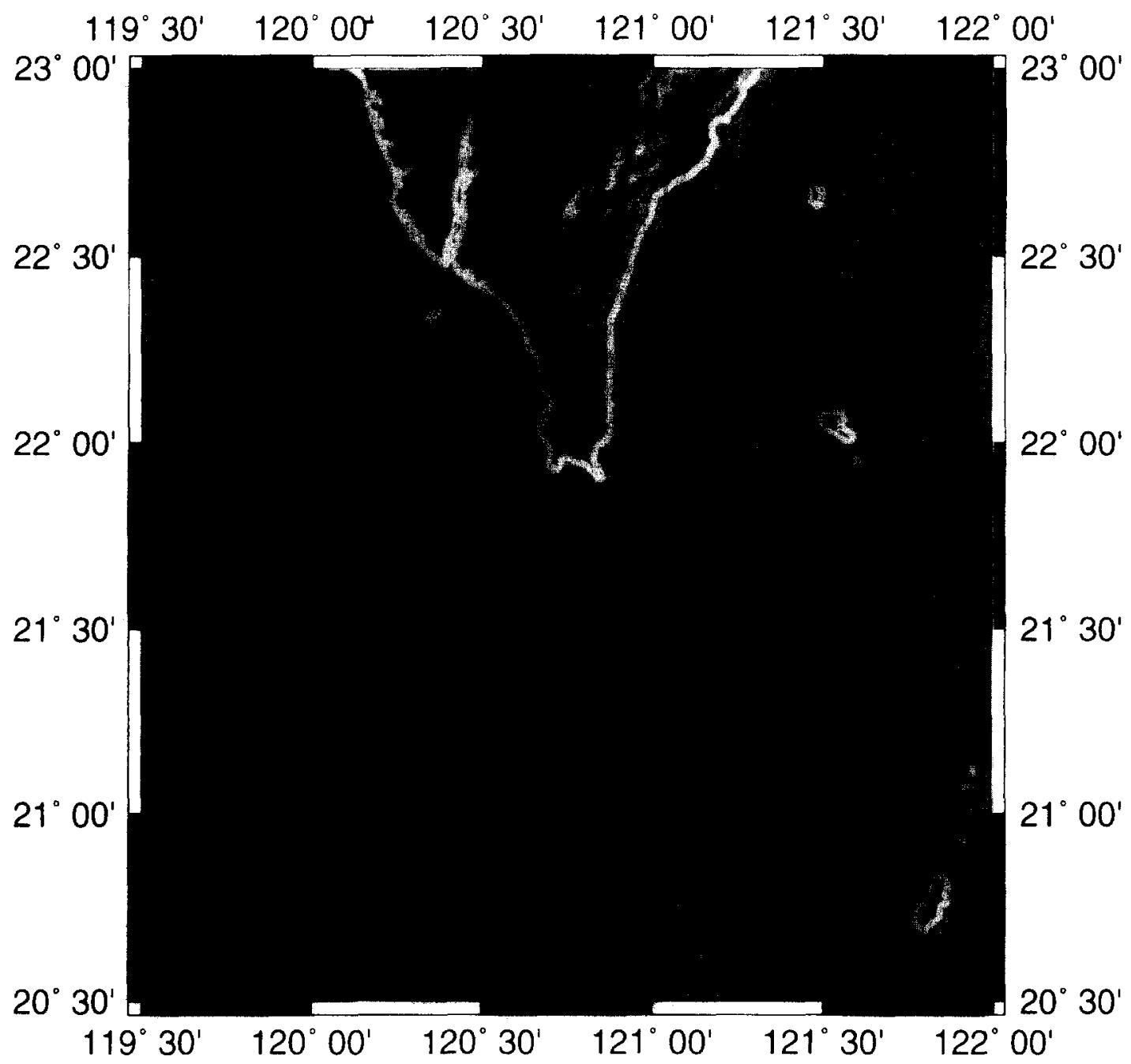

Fig. 2. Shaded topographic map of the study area with $200-\mathrm{m}$ bathymetric contours overlay. The direction of the light is from SE to emphasize NE-SW-trending topographic lineaments. $C C M=$ Chinese continental margin; $C R=$ Central Range; $H P=H e n g c h u n$ Peninsula; $H R=$ Hengchun Ridge; $H T R=$ Huatung Ridge: $L V=$ Longitudinal Valley; $M T=$ Manila Trench; $N L T=$ North Luzon Trough; $N T T=$ Northern Taitung Trough; $S C S=$ South China Sea; $S L T=$ Southern Longitudinal Trough; STT $=$ Southern Taitung Trough.

tionary wedge), the North Luzon Trough (forearc basin), and the Luzon arc present a configuration of a classical arc-trench system (Lundberg et al.. 1992; Reed et al., 1992). Two structural domains have been recognized along the trench side of the accretionary wedge: a lower slope domain which is composed of NNW-trending, mostly W-vergent ramp anticlines and thrusts, and an intensely deformed, mostly reflection-free upper slope domain (Reed et al., 1992). East-vergent back thrusts are observed along the arcward side of the accretionary wedge, though south of about $21^{\circ} 15^{\prime} \mathrm{N}$ the back thrust is blind and lies underneath the upturned strata of the North Luzon Trough (Reed et al., 1992). The closure of the forearc basin north of about $21^{\circ} 20^{\prime} \mathrm{N}$ is discussed in detail by Lundberg et al. (1997).

The relationships of the tectonic provinces onland and offshore southern Taiwan have been considered in various previous studies. The Coastal Range and the Longitudinal Valley onland Taiwan are the postcollisional equivalence of the Luzon volcanic arc and the North Luzon Trough (Lundberg et al., 1991; 
Huang et al., 1992). The Central Range extends southward and connects to the upper slope domain of the accretionary wedge offshore southern Taiwan. On the western side of this collision-subduction system, the Western Foothills province onland Taiwan should correlate to the lower slope domain of the accretionary wedge offshore (Liu et al., 1996). The crescent shape of the thrust wedge extends from onland Taiwan in the north to the submarine accretionary wedge in the south.

\section{Evidence of the strike-slip faults}

Three sets of strike-slip faults have been identified in the area off southern Taiwan (Fuh et al., 1994): the roughly N-S-trending left-lateral strike-slip faults observed within the Luzon arc; the NE-SW-trending right-lateral strike-slip faults observed in the central and rear flank of the accretionary wedge; and the NNE-SSW-trending left-lateral strike-slip fault identified in the lower slope domain of the accretionary wedge. These strike-slip faults overprint the pre-existing folds and thrusts. The locations and orientations of the strike-slip faults can be better constrained from detailed bathymetry data.

Fig. 2 is a shaded topographic map of the study area overlain with bathymetric contours. In order to emphasize the NE-SW-trending structures, the light is projected from the southeast direction. Several NE-SW-trending topographic lineaments running across the accretionary wedge can be clearly seen, which may indicate locations of the right-lateral strike-slip faults. The left-lateral strike-slip fault observed at the frontal portion of the accretionary wedge may be correlated to a NNE-SSW-trending topographic lineament (Fig. 2). Due to the en-echelon pattern of the Luzon arc, it is difficult to identify a N-S-trending topographic lineament which corresponds to the left-lateral strike-slip fault system within the Luzon arc. Thus this fault system may not appear as a narrow strike-slip fault. Rather, the left-lateral strike-slip faults associated with this fault system may be distributed in a shear zone across the width of the Luzon arc.

Fig. 3 is a simplified structural map of the study area compiled from Reed et al. (1992), Fuh et al. (1994) and Liu et al. (1996), and constrained by the sea floor topography (Fig. 2). The geometric

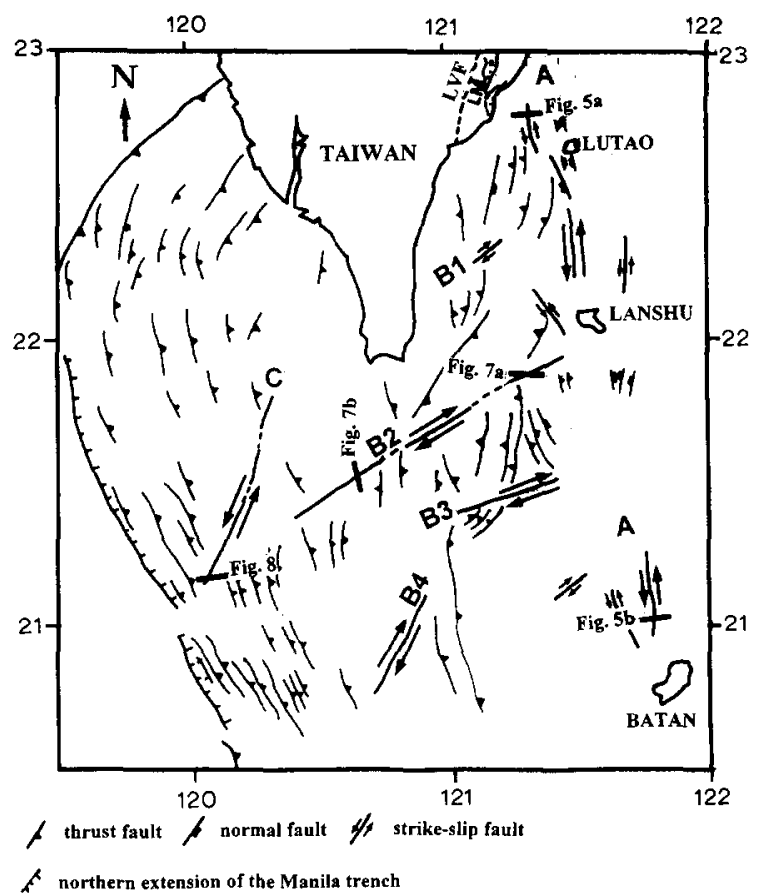

Fig. 3. Simplified structural map of the study area. Fault system A (labeled A) consists of several left-lateral strike-slip faults located within the Luzon arc. Right-lateral strike-slip faults B1, B2, B3 and B4 belong to the fault system B in the central and rear side of the accretionary wedge and forearc basin area. Fault system C is represented by a NNE-SSW-trending left-lateral strike-slip fault (labeled C). Locations of the seismic sections shown in Figs. 5, 7 and 8 are marked by thick bars. $L M=$ Lichi melange. $L V F=$ Longitudinal Valley fault.

pattern of the strike-slip faults appearing on this structural map fits well with the bookshelf rotation model proposed by Fuh et al. (1994) (Fig. 4). The mechanism of this model and its implication will be discussed in later sections, here we present further evidences for the existence of the strike-slip faults.

\subsection{Strike-slip fault system associated with the Luzon volcanic arc}

Due to the chaotic nature of the seismic reflection signals from the volcanic arc material, it is difficult to observe strike-slip structures on the seismic profiles over this region. Fig. 5 shows two seismic sections running across the Luzon arc in an $\mathrm{E}-\mathrm{W}$ direction which are located to the northwest of the islands Lutao and Batan, respectively (Fig. 3). Both sections reveal similar structural patterns with abrupt 


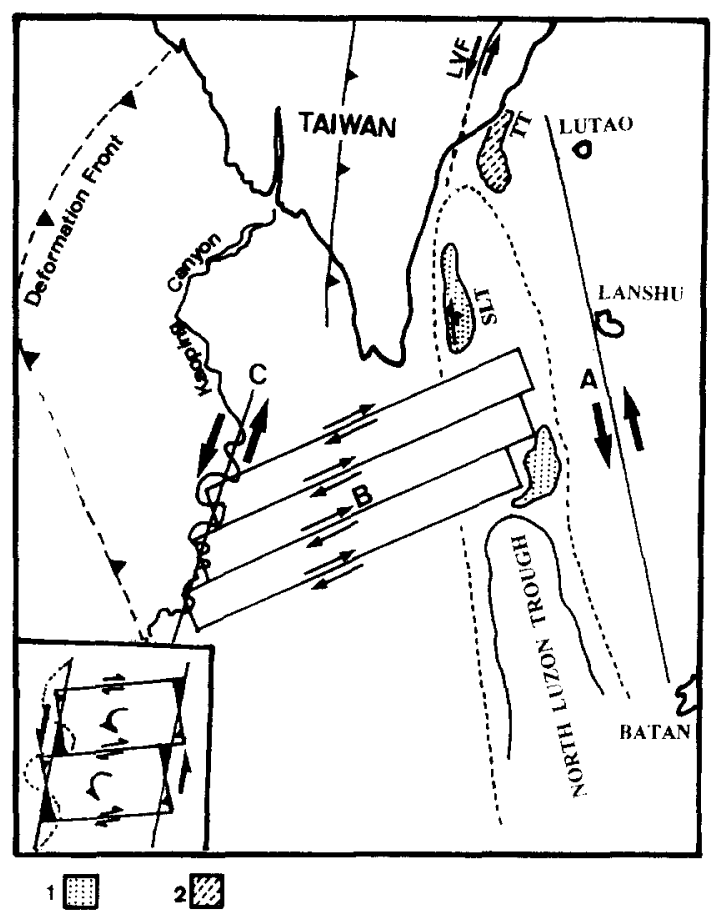

Fig. 4. The bookshelf rotation model showing the structural pattern of the strike-slip fault systems observed (labeled A, B and C). $L V F=$ Longitudinal Valley fault: $S L T=$ Southern Longitudinal Trough; $T T=$ Taitung Trough. Dotted and shaded patterns labeled 1 and 2 indicate locations of suture or proto-collisional basins. Inset in the lower left corner shows that gaps (darkened area) and overlaps (open saw tooth) may develop along the boundary between the rotating blocks and bounding faults. Dotted line in the inset represents the meandering Kaoping Canyon which may be controlled by the block rotation process.

vertical offset of the sea floor, vertical offset of nearhorizontal reflectors, and the convergent fault zones. These structural styles are interpreted to be those of the strike-slip faults. The distribution of the strikeslip faults identified by Fuh et al. (1994) within the Luzon arc zone suggests that those strike-slip faults are sub-parallel to one another rather than aligned into a single narrow strike-slip fault zone.

Another evidence for the existence of a left-lateral strike-slip fault system within the Luzon arc comes from studies of earthquake focal-mechanism (Fig. 6). Lewis and Hayes (1989) proposed that there are NW-SE-trending left-lateral strike-slip faults along the eastern side of the Luzon volcanic arc. Many other studies have also suggested the existence of left-lateral strike-slip faults with a NNW-trend in the area just east of Lutao Island (Katsumata and Sykes, 1969; Seno and Kurits, 1978; Lin and Tsai, 1981; Chen and Wang, 1986; Cheng and Yeh, 1991). Concentrated seismicity near the Luzon volcanic arc suggests that the inferred strike-slip fault system is still active.

\subsection{Strike-slip faults within the accretionary wedge}

Several roughly NE-SW-trending strike-slip faults have been identified in the central part of the accretionary wedge and forearc basin (Fig. 3). The interpreted right-lateral motion of these faults is mainly based on the offset of the gravity and magnetic anomalies (Liu et al., 1992; Fuh et al., 1994) and some topographic features (Fig. 2). Fault B1 cuts across the Huatung Ridge and may extend further eastward to cut across the Luzon arc between the islands of Lutao and Lanhsu. Evidences other than bathymetry are needed to confirm this. Fault B2 is the most prominent NE-SW-trending strike-slip fault observed on the sea floor topography (Fig. 2). Seismic profiles which run across this inferred fault zone show characteristic structural patterns of strikeslip faulting. Fig. 7 presents two seismic sections which run across the inferred fault near the eastern and western ends, respectively. The upper figure shows structural patterns with abrupt vertical offset of the sea floor, vertical offset of the sedimentary strata and the basement reflections, and the convergent fault planes. The lower figure shows a structural pattern of down-dropping of the deep reflections and the convergence of fault planes, which is interpreted as a negative flower structure. Both sections suggest the existence of a strike-slip fault.

Fault B3 corresponds to the location of a large offset on both magnetic and gravity anomalies (Fuh et al., 1994). Fault B4, first identified by Fuh et al. (1994), correlates well with a distinctive NNE-SSWtrending topographic lineament observed in Fig. 2 , thus strengthens the interpretation for the existence of a strike-slip fault there.

\subsection{Strike-slip faults in the frontal portion of the accretionary wedge}

Fuh et al. (1994) have identified a NNE-SSWtrending left-lateral strike-slip fault system (marked as $C$ in Fig. 3) from several seismic sections across 


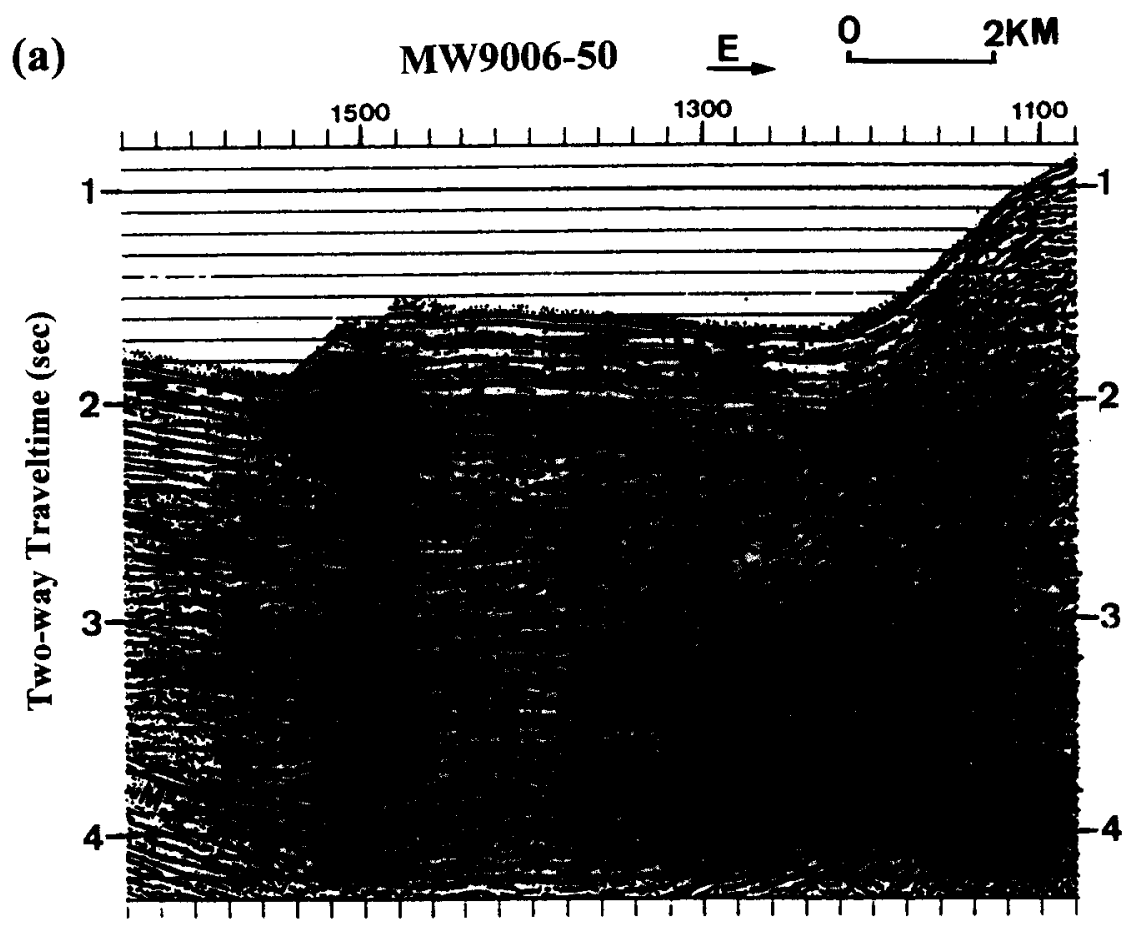

(b)

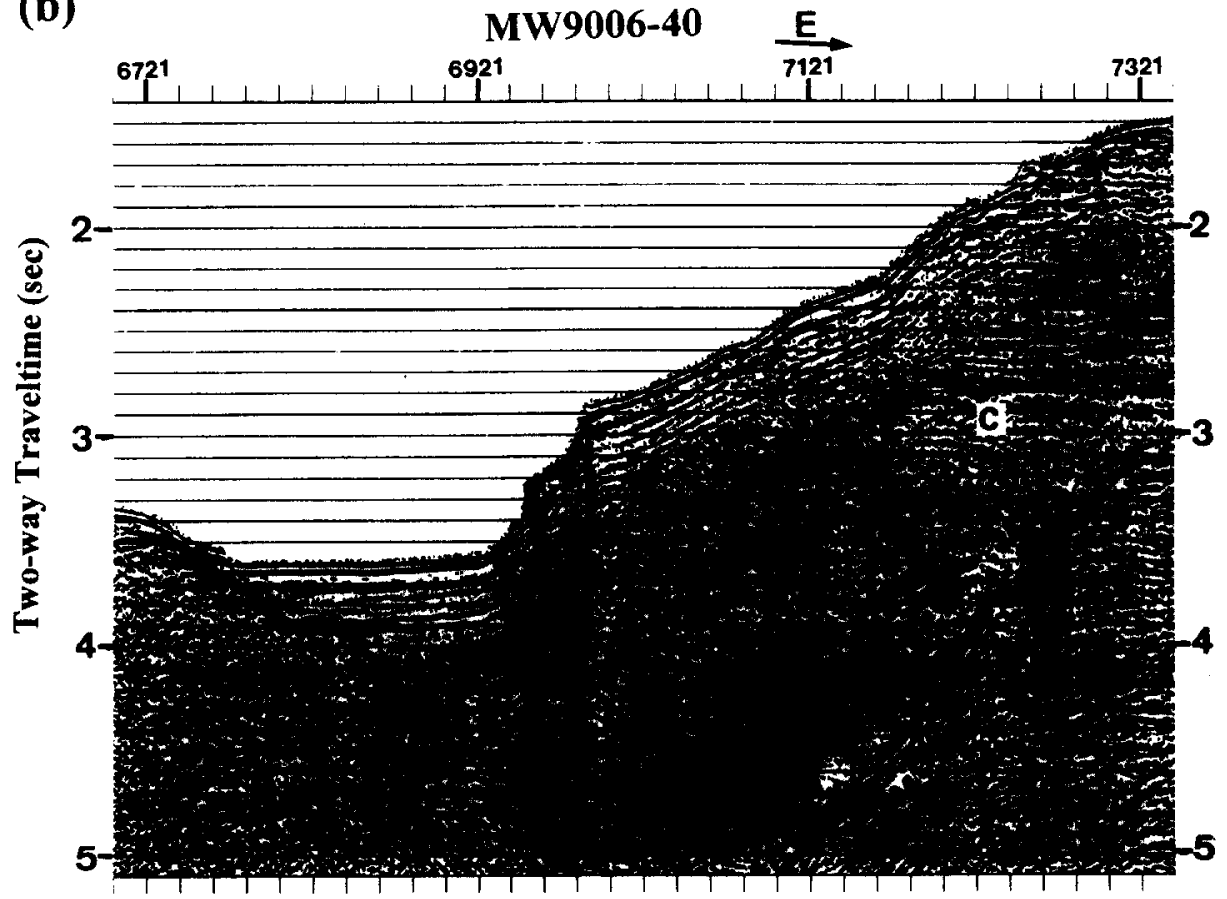

Fig. 5. Two interpreted seismic reflection profiles crossing the strike-slip fault system A. (a) Profile MW9006-50 lies near the northern end of fault system A. (b) Profile MW9006-40 located at the southern end of fault system A (see Fig. 3 for profile locations). Strike-slip faults are identified by the vertical offset of the sea floor and the convergent fault planes. Reflector $\mathrm{C}$ is interpreted volcanic arc basement. $M$ marks the multiple reflections. 


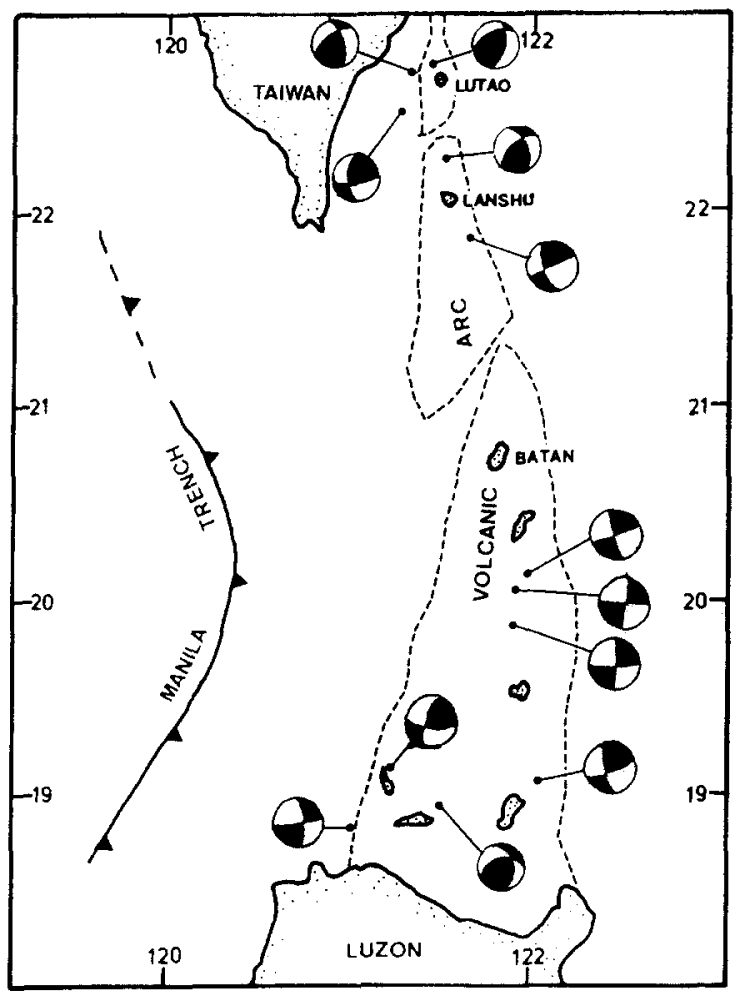

Fig. 6. Earthquake focal mechanism solutions in the Luzon arc zone. Only solutions showing strike-slip motion are plotted here to demonstrate the left-lateral component of the relative plate motion. Selected from Cheng and Yeh (1991).

the lower-slope domain of the accretionary wedge based on the observation of the near-vertical fault surface, vertical offset of near-horizontal reflectors, vertical offset of sea bed, and converging fault traces. Seismic section MW9006-36 (Fig. 8) shows a basement-involved negative flower structure. The meandering course of the lower section of the Kaoping Canyon (Liu et al., 1993) is very likely controlled by this fault system.

\section{Discussion on the mechanism of strike-slip faulting}

Lu and Malavieille (1994) conducted experimental modeling to study the oblique convergence, indentation, and rotational tectonics in the Taiwan mountain belt. Their study indicates that a right-lateral shear zone will be developed to the left of the indenter (volcanic arc), while left-lateral bookshelf rotation associated strike-slip faulting, as described by Tapponnier et al. (1990), will appear in the internal part of the accretionary wedge (mountain belt). The right-lateral strike-slip faults (fault system B) in the central part of the accretionary wedge delineated in our study may correspond to simple shear deformation, while the left-lateral strike-slip fault systems associated with the volcanic arc (fault system A) and that in the frontal portion of the accretionary wedge (fault system C) may represent boundingcoupled shear that allow this left-lateral bookshelf rotation (Figs. 3 and 4). In the experiment of $\mathrm{Lu}$ and Malavieille (1994), the 'dipping backstop' simulating the volcanic arc is not to be deformed. This conflicts with the fact that the volcanic arc is a weak zone in the overriding plate and could easily be deformed during the collision process (Beck, 1983). The structural pattern observed may thus deviate from that in the experimental modeling.

Our interpretation of the strike-slip fault geometry can be explained in a simplified structural map (Fig. 4). The two left-lateral strike-slip fault systems $\mathrm{A}$ and $\mathrm{C}$ act as the two bounding faults which caused rotation of the forearc blocks and induced the rightlateral strike-slip faults (fault system B) observed within the accretionary wedge and forearc basin. As shown in the lower left inset of Fig. 4, block rotation induced by coupled shear may cause overlaps (small reverse faults) and gaps (small normal faults) to form along major bounding faults (Dibblee, 1977). Normal faults observed north of the eastern ends of right-lateral strike-slip faults B1 and B3 may be induced by the block rotation process. The negative flower structure associated with the bounding fault C suggests the existence of block-rotation related normal faults. Meandering of the lower course of the Kaoping Canyon could also be controlled by the small reverse and normal faults developed along the bounding fault $\mathrm{C}$ (see inset of Fig. 4).

Evidence for the existence of strike-slip fault system $\mathrm{C}$ may be more disputable than that of fault systems A and B. But the existence of such a bounding fault is highly possible for the following reason. As the frontal portion of the accretionary wedge approaches the continental margin of the South China Sea obliquely, the thick continental crust of the passive continental margin resists to going down with the subducting plate which causes deformation of 

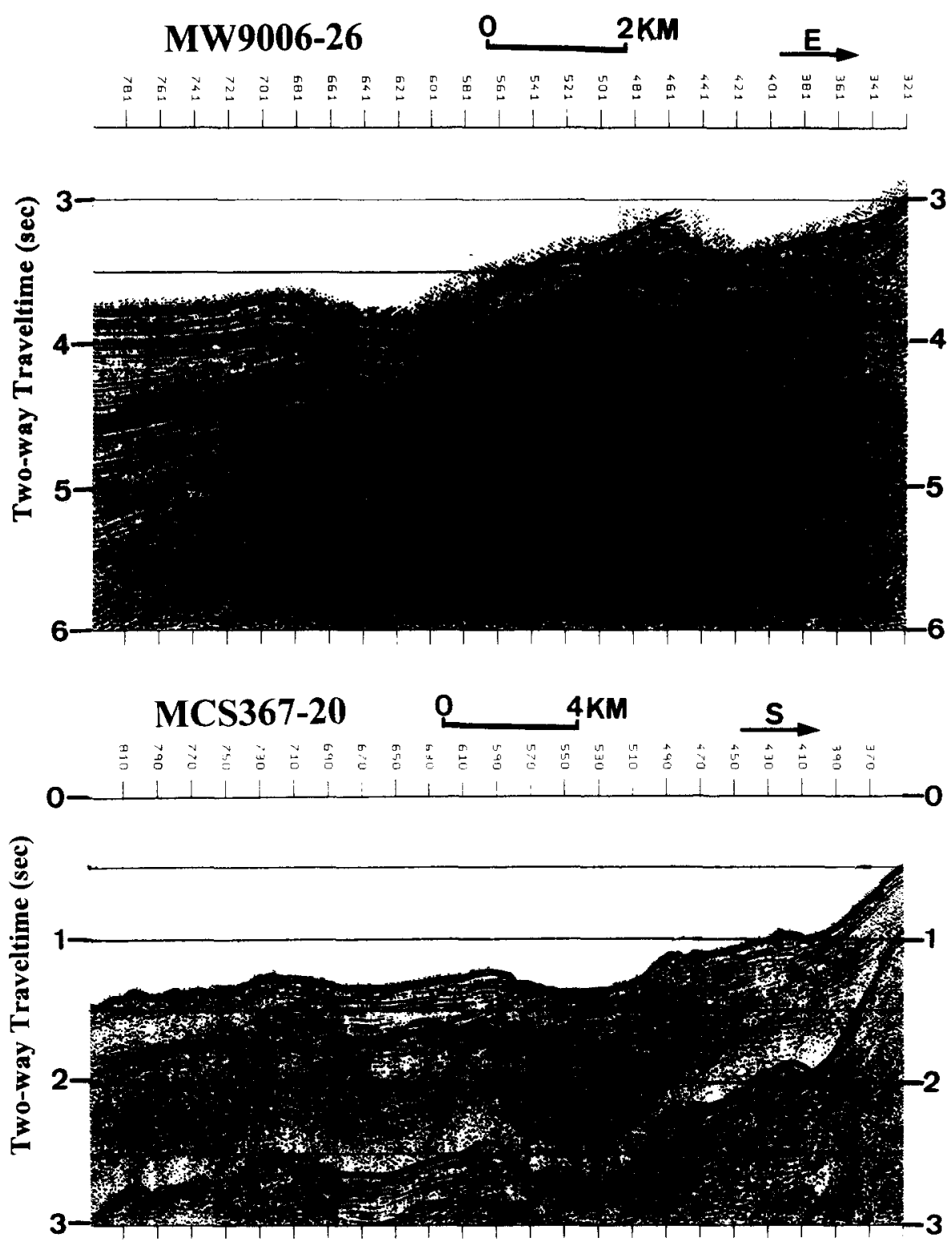

Fig. 7. Two interpreted seismic reflection profiles, MW9006-26 and MCS367-20, showing strike-slip structures of fault B2. Profile locations are shown in Fig. 3.

the overriding plate. Strike-slip fault may be developed along the frontal portion of the accretionary wedge in a direction parallel to the continental margin due to the tangential component of the oblique convergence. Results from physical modeling of the oblique arc-continent collision process (Huang et al., 1995) confirm the existence of such strike-slip faults parallel to the continental margin.

\section{Implications for evolution of proto-collisional basins}

The bookshelf rotation concept is applied to investigate the development of the proto-collisional basins observed in the area off southeastern Taiwan, such as the Southern Longitudinal Trough and the Taitung Trough (Fig. 2). Lundberg et al. (1997) sug- 

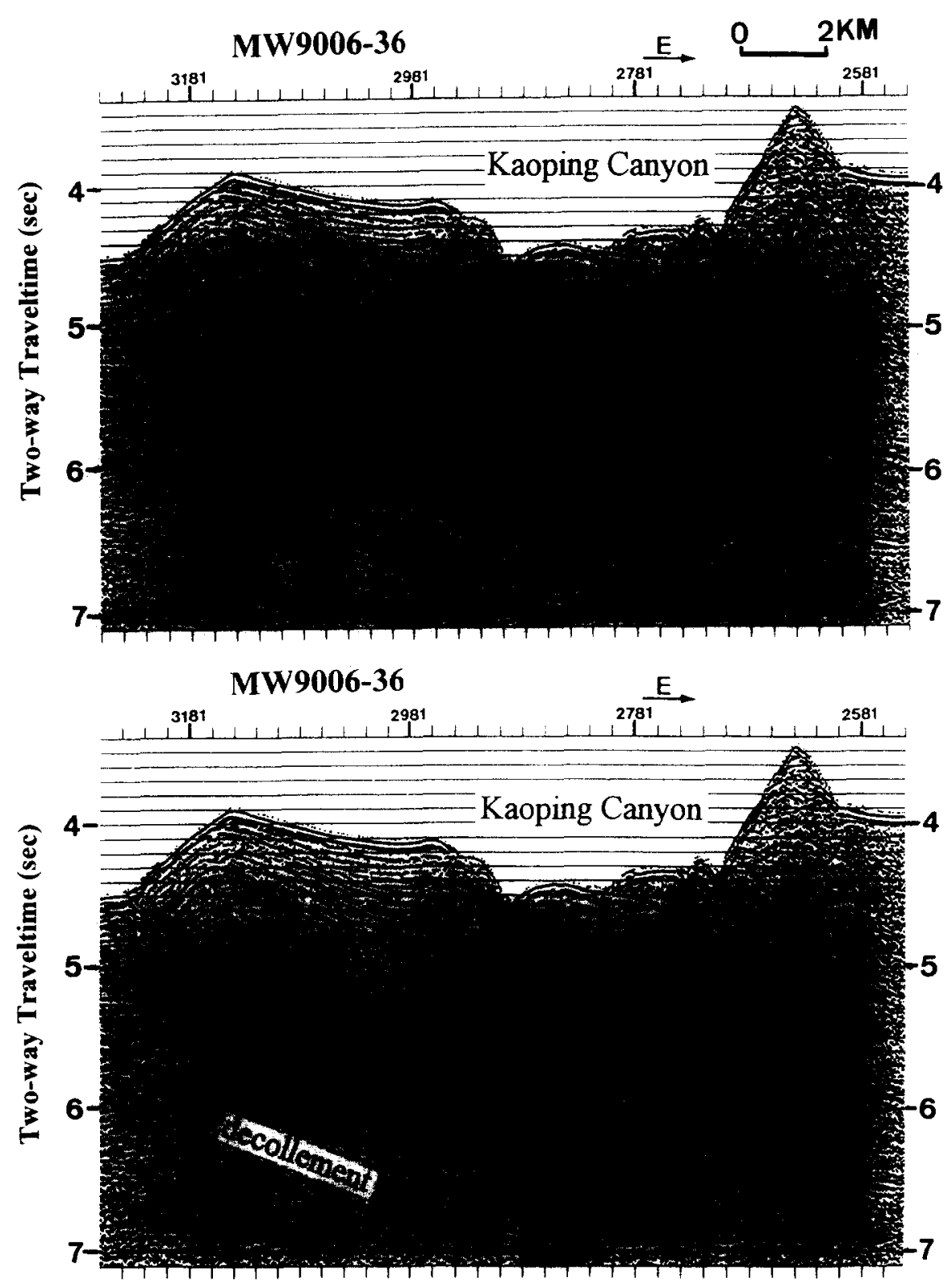

Fig. 8. Seismic reflection profile MW9006-36 (upper profile) and its interpreted section (lower profile). Profile location is shown in Fig. 3. Negative flower structure is observed below the Kaoping Canyon.

gest that the closure of the forearc basin is mainly due to the arcward vergence of the accretionary wedge and forearc basin in the region of arc accretion. The collisional basins, such as the Taitung Trough, are thus formed by backthrusting of the accretionary wedge and forearc basin material (such as the Huatung Ridge) over the western flank of the
Luzon arc. We agree that backthrusting is a major mechanism for the deformation along the rear of the accretionary wedge and the closure of the forearc basin. However, the block rotation process caused by the oblique convergence may be superimposed on the thrusting process to cause a part of the accretionary wedge being extruded into the forearc basin 
and a part of the forearc-basin strata being uplifted, forming the Huatung Ridge.

Some of the collisional basins, such as the southern portion of the Taitung Trough south of about $22^{\circ} 20^{\prime} \mathrm{N}$, are clearly formed by the arcward movement of the deformed and uplifted accretionary wedge and forearc basin material. However, normal faulting structures have been observed within other collisional basins (Fig. 3). The bookshelf rotation process which induces normal and reverse faults along the bounding fault zone may provide a good alternative explanation for the observed structures. The Southern Longitudinal Trough and the northern section of the Taitung Trough thus could be interpreted as block-rotation related proto-collisional basins.

\section{Tectonic evolution of the oblique arc-continent collision process}

Due to the oblique convergence of the Luzon arc with the Chinese continental margin, the Taiwan arc-continent collision process is propagating southward at a rate of about $85 \mathrm{~km} / \mathrm{m}$.y. (Suppe, 1984). Comparison of structural patterns observed onland and offshore Taiwan may provide us information on the development of this oblique collision process. Sequential changes of structural styles and fault trace orientations during the oblique collision processes have been reported in the sand-box modeling experiments of $\mathrm{Lu}$ and Malavieille (1994). The strike-slip faults which are observed in a region where the collision process is just commencing may become inactive or even be converted into a different structure as the collision process progresses. With this concept in mind, strike-slip fault structures can be incorporated into the thrust domain to infer the evolution of oblique arc-continent collision processes. The relationships of the tectonic provinces onland and offshore southern Taiwan can also be established.

We propose a four-stage evolutionary model for the oblique arc-continent collision of the Taiwan mountain belt (Fig. 9). This model emphasizes sequential developments of the structures rather than the age of each collisional event. Different structural patterns proposed at different stages of the oblique arc-continent collision can be related to different structures observed at various places along the Taiwan arc-continent collision belt from south to north.

Fig. $9 \mathrm{a}$ illustrates the beginning stage of the oblique convergent process. Left-lateral strike-slip faults may begin to develop within the Luzon volcanic arc along a direction sub-parallel to the trench (marked as 1A in Fig. 9a). A major structure observed at this stage is an asymmetrical thrust wedge which is developed as a consequence of oblique collision by an asymmetrical indenter ( $\mathrm{Lu}$ and Malavieille, 1994).

As the thrust wedge impinges upon the Chinese continental margin, some left-lateral strike-slip faults may develop in the frontal portion of the wedge (marked as 1C in Fig. 9b) sub-parallel to the Chinese continental margin. This strike-slip fault system together with the strike-slip fault system developed earlier within the Luzon volcanic arc form a coupled shear which then induce left-lateral bookshelf rotation for part of the offshore accretionary wedge (Fig. 9b). A series of right-lateral strike-slip faults (marked as 1B in Fig. 9b) are developed within the accretionary wedge owing to this left-lateral bookshelf rotation. These strike-slip faults cut across previously formed thrusts. Block rotation may also cause extrusion of the accretionary wedge material into the forearc basin that closes the forearc basin and turns it into a proto-collisional basin.

When the Luzon volcanic arc encounters the Chinese continental margin, it is bent and deformed, and rotates clockwise (Fig. 9c). The clockwise rotation of the Coast Range blocks has been reported by Lee et al. (1991), while the geodetic measurements across the Longitudinal Valley reported by Yu et al. (1990) and the GPS velocity field reported by Yu and Chen (1994) have showed a systematic variation of the relative motion of the Coastal Range blocks from south to north. Bending or clockwise rotation of the frontal portion of the Luzon volcanic arc form an en-echelon pattern of the Coastal Range structures. The Longitudinal Valley fault, which cuts through the collisional basin (marked $1 \mathrm{X}$ in Fig. 9c) and extruded forearc blocks, may begin to develop. Most of the right-lateral strike-slip faults developed within the previously formed rotated blocks (marked $1 \mathrm{~B}$ in Fig. 9c) have impinged onto the Chinese continental margin and have gradually been converted into oblique thrusts or thrusts. At the same time, new 

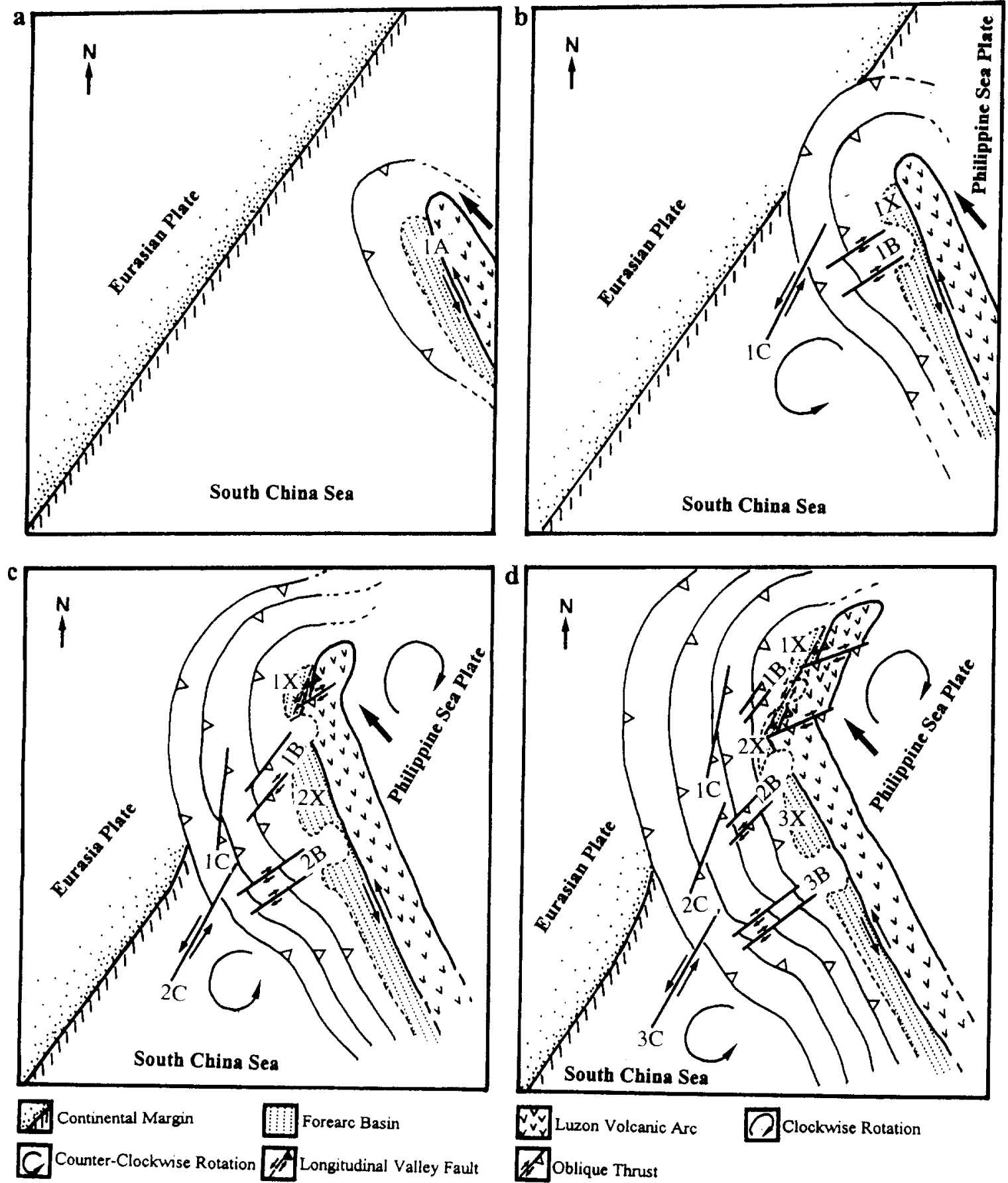

SOblique Thrust

Fig. 9. Tectonic evolution model for the oblique arc-continent collision of Taiwan. (a) Oblique subduction stage. Major structure developed is an asymmetrical thrust wedge. (b) Initial oblique collision stage. Strike-slip faults associated with counter-clockwise rotation (labeled $\mathrm{IB}$ and $\mathrm{IC}$ ) of the accretionary wedge overprint the previously formed thrust wedge. Proto-collisional basin $(I X)$ is formed. (c) Arc accretion stage. The thrust wedge develops into a mountain belt. Strike-slip faults IB and IC which were formed in the offshore area earlier are converted into oblique thrusts or thrusts as these structures are accreted onland. The Luzon volcanic arc bents eastward and rotates clockwise. Proto-Longitudinal Valley and associated faults are formed. In the offshore region, new sets of strike-slip faults (2B and $2 \mathrm{C}$ ) and a proto-collisional basin $(2 X)$ are developed. (d) Oblique collision process moves southward and an en-echelon structural pattern of the Coastal Range is developed. 
sets of strike-slip faults are developed in the offshore accretionary wedge (marked $2 \mathrm{~B}$ and $2 \mathrm{C}$ in Fig. 9c).

Bending of the Luzon volcanic arc continues as the thrust wedge of the Taiwan mountain belt grows. The Longitudinal Valley extends further south, and the previously formed right-lateral strike-slip faults developed due to the counter-clockwise block rotation (fault $2 \mathrm{~B}$ in Fig. 9d) gradually turn into oblique thrusts and thrusts. Newly developed counter-clockwise block rotation within the offshore accretionary wedge creates another set of strike-slip faults and proto-collisional basins (marked 3B and 3X, respectively, in Fig. 9d).

Based on the tectonic evolutionary model proposed above, the Coastal Range and the Longitudinal Valley onland Taiwan are the post-collisional equivalence of the deformed Luzon volcanic arc and North Luzon Trough (including some proto-collisional basins and extruded forearc blocks). The material within the upper slope domain of the accretionary wedge (the Hengchun Ridge) offshore southern Taiwan is to be exhumed to form the southern extension of the Central Range.

\section{Conclusions}

Taiwan is the site of active arc-continent collision. Previous studies of the Taiwan mountain belt emphasize the convergent structural styles of folds and thrusts observed onland and offshore southern Taiwan. However, due to the oblique convergence of the Luzon arc toward the Chinese continental margin, strike-slip faults also play an important role in the development of the Taiwan collision processes. By utilizing the newly available digital bathymetry data in the area offshore southern Taiwan, we have identified several linear topographic features which may be related to fault structures. Seismic reflection profiles are then examined to check the validity of the interpreted strike-slip faults.

We confirm the existence of three sets of strikeslip faults which overprint the dominant thrust structures in the Luzon arc-trench system offshore southern Taiwan. The first set of the strike-slip faults are located within the Luzon arc with a roughly $\mathrm{N}-\mathrm{S}$ trend. These left-lateral strike-slip faults do not fall in a narrow fault zone; rather they are distributed in a broad shear zone across the width of the Luzon arc. The existence of this fault zone has also been supported by the left-lateral earthquake focal mechanism solutions observed along the Luzon arc region. The second set of the strike-slip faults are right-lateral but may not display large horizontal movements. These faults are located within the central portion of the accretionary wedge and may extend to the forearc basin. The third set of the strike-slip faults lie in the frontal portion of the accretionary wedge and are interpreted to be left-lateral in motion. A left-lateral bookshelf rotation model is used to explain the observed strike-slip fault geometry: the two left-lateral strike-slip fault systems behave as the bounding faults of the bookshelf rotation which induce the counter-clockwise rotation of the central blocks and thus generate a series of right-lateral strike-slip faults in the accretionary wedge.

As a consequence of the oblique convergence and left-lateral bookshelf rotation, blocks of the accretionary wedge material may extrude into the forearc basin and lift up the forearc strata and basement. The originally continuous forearc basin is thus deformed into several closed and separated proto-collisional basins, such as the Southern Longitudinal Trough and the Taitung Trough off southeastern Taiwan. Since block rotation may cause overlaps and gaps to form along the major bounding faults, both thrusts and normal faults may occur in the proto-collisional basins. This may explain the observed extensional structures in the northern Taitung Trough and in the Southern Longitudinal Trough.

Based on the spatial distribution of the structural patterns and analyses of their developments, we propose a tectonic evolution model for the oblique arc-continent collision processes in Taiwan. In this model, the left-lateral strike-slip faults observed within the Luzon arc are induced due to the oblique convergent direction of the Luzon arc to the Chinese continental margin. Another set of left-lateral strike-slip faults may have developed at the frontal portion of the accretionary wedge as the accretionary wedge approaches the thick continental crust basement. Counter-clockwise bookshelf rotation is thus developed producing right-lateral strikeslip faults within the accretionary wedge and forearc basin. As the arc is being accreted to the continental margin, the strike-slip faults developed offshore are converted gradually into thrusts, the arc itself being 
bent and rotated in a clockwise direction. Right-lateral strike-slip faults may form within the Luzon arc due to the bending and clockwise rotation of the arc blocks which result in an en-echelon pattern of the Coastal Range. This proposed model is compatible with the observed structures onland Taiwan and in the incipient collision zone offshore southern Taiwan.

\section{Acknowledgements}

The authors would like to thank H.S. Yu and H.T. Chun for their critical reviews of this work. Helpful discussions offered by K.M. Yang, A. Shemenda and J.C. Wu are acknowledged. Comments and suggestions made by three anonymous reviewers helped to improve the manuscript significantly. The acquisition of the MW9006 data was supported by the National Science Council (NSC) of the Republic of China (NSC79-0209-M002A-14 to C.S. Liu) and the National Science Foundation of the U.S.A. (OCE8911507 to N. Lundberg and D. Reed). This research was supported by NSC through grant NSC82-0209M002A-042 to C.S. Liu.

\section{References}

Beck. Jr.. M.E.. 1983. On the mechanism of tectonic transport in zones of oblique subduction. Tectonophysics, 93:1-11.

Biq, C.C., 1973. Kinematic pattern of Taiwan as an example of actual continent-arc collision. Report of the Seminar on Seismology. US-ROC Cooperative Science Program. pp. 2126.

Bowin, C., Lu, R., Lee. C.S. and Shouten. H.. 1978. Plate convergence and accretion in Taiwan-Luzon region. Am. Assoc. Pet. Geol. Bull., 62: 1645-1672.

Cheng, S.N. and Yeh. Y.T. 1991. Seismotectonics of the Taiwan Luzon region as evidenced from seismicity and focal mechanism of earthquakes. TAICRUST Workshop Proceedings, National Taiwan University, pp. 219-226.

Dibblee, T.W., 1977. Strike-slip tectonics of the San Andreas fault and its role in Cenozoic basin development. In: Late Mesozoic and Cenozoic Sedimentation and Tectonics in California. San Joaquin Geological Society Short Course. pp. 26-38.

Dorsey, R.J., 1992. Collapse of the Luzon volcanic arc during onset of arc-continent collision: evidence from a MiocenePliocene unconformity, eastern Taiwan. Tectonics, 11(2): 177-191.

Fitch, T.J., 1972. Plate convergence, transcurrent faults, and internal deformation adjacent to Southeast Asia and the western Pacific. J. Geophys. Res., 77(23): 4432-4460.
Fuh, S.C., Liu, C.S. and Song, G.S., 1994. Decoupled transcurrent faults in the offshore area south of Taiwan. Pet. Geol. Taiwan, 29: 27-46.

Ho, C.S., 1986. A synthesis of the geologic evolution of Taiwan. Tectonophysics, 125: 1-16.

Huang, C.Y., Shyu, C.T., Lin, S.B., Lee, T.Q. and Sheu, D.D., 1992. Marine geology in the arc-continent collision zone off southeastern Taiwan: implication for late Neogene evolution of the Coastal Range. Mar. Geol., 107: 183-212.

Huang, C.Y., Yuan, P.B., Song, S.R., Lin, C.W., Wang, C., Chen. M.T., Shyu, C.T. and Karp, B., 1995. Tectonics of short-lived intra-arc basin in the arc-continent collision terrain of the Coastal Range, eastern Taiwan. Tectonics, 14: 19-38.

Karig. D.E., 1973. Plate convergence between the Philippines and the Ryukyu Islands. Mar. Geol., 14: 153-168.

Katsumata, M. and Sykes, L.R., 1969. Plate convergence and deformation, North Luzon Ridge, Philippines. Tectonophysics. 168: $221-237$.

Lee, T.Q., Kissel. C., Barrier, E., Lai. C. and Chi, W.R., 1991. Paleomagnetic evidence for a diachronic clockwise rotation of the Coastal Range. Earth Planet. Sci. Lett., 104: 245-257.

Lewis, S.D. and Hayes, D.E., 1989. Plate convergence and deformation, North Luzon Ridge, Philippines. Tectonophysics, 168 : $221-237$.

Lin, M.T. and Tsai, Y.B., 1981. Seismotectonics in TaiwanLuzon area. Bull. Inst. Earth Sci. Acad. Sinica, 1: 51-82.

Liu, C.S., Liu, S.Y., Kuo, B.Y., Lundberg, N. and Reed, D.L., 1992. Characteristics of the gravity and magnetic anomalies off southern Taiwan. Acta Geol. Taiwan., 30: 123-130.

Liu, C.S. Lundberg, N., Reed, D. and Huang, Y.L., 1993. Morphological and seismic characteristics of the Kaoping Submarine Canyon. Marine Geol., 111: 93-108.

Liu, C.S., Huang, I.L. and Teng, L.S., 1996. Structural features off southwestern Taiwan. Mar. Geol., in press.

Lu. C.Y. and Malavieille, J., 1994. Oblique convergence, indentation and rotation tectonic in the Taiwan mountain belt: insights from experimental modeling. Earth Planet. Sci., Lett., 121: $477-494$.

Lundberg. N. and Dorsey, R.J., 1988. Synorogenic sedimentation and subsidence in a Plio-Pleistocene basin, eastern Taiwan. In: K.L. Kleinspehn and C. Paola (Editors), New Perspectives in Basin Analysis. Springer-Verlag, New York, pp. 265 280 .

Lundberg, N., Reed, D.L. and Liu, C.S., 1991. The submarine propagation tip of the Taiwan collision: shallow crustal structure and orogenic sedimentation. TAICRUST Workshop Proceedings, National Taiwan University, pp. 93-102.

Lundberg. N., Reed, D.L., Liu, C.S. and Lieske, Jr., J., 1992. Structural controls on organic sedimentation, submarine Taiwan collision. Acta Geol. Taiwan., 30: 131-140.

Lundberg, N., Reed, D.L.. Liu, C.S. and Lieske, Jr., 1997. Forearc-basin closure and arc accretion in the submarine suture zone south of Taiwan. In: S.E. Lallemand and H.-H. Tsien (Editors), Active Collision in Taiwan. Tectonophysics. 274: 5-23 (this issue).

Reed, D.L., Lundberg, N., Liu, C.S. and Kuo, B.Y., 1992. Structural relations along the margins of the offshore Tai- 
wan accretionary wedge: implications for accretion and crustal kinematics. ACTA Geol. Taiwan., 30: 105-122.

Seno, T., 1977. The instantaneous rotation vector of the Philippine Sea Plate. Tectonophysics, 42: 209-226.

Seno, T. and Kurits, D., 1978. Focal mechanisms and tectonics in the Taiwan Philippine region. In: S. Uyeda, R.W. Murphy and K. Kobayashi (Editors), Geodynamics of the Western Pacific, J. Phys. Earth Suppl. Iss., pp. 249-263.

Suppe, J., 1984. Kinematics of arc-continent collision, flipping of subduction, and back-arc spreading near Taiwan. Mem. Geol. Soc. China, 6: 21-33.
Tapponnier, P., Armijo, R., Manighetti, I. and Courtillot, V., 1990. Bookshelf faulting and horizontal block rotation between overlapping rifts in southern Afar. Geophys. Res. Lett., 17: 1-4.

Teng, L., 1990. Geotectonic evolution of late Cenozoic arc-continent collision in Taiwan. Tectonophysics, 183: 57-76.

Yu, S.B. and Chen, H.Y., 1994. Global Positioning System measurements of crustal deformation in the Taiwan arc-continent collision zone. TAO, 5: 477-498.

Yu, S.B., Jackson, D.D., Yu, G.K. and Liu, C.C., 1990. Dislocation model for crustal deformation in the Longitudinal Valley area, eastern Taiwan. Tectonophysics, 183: 97-109. 